\title{
Sciendo
}

DOI 10.2478/afepuc-2021-0014

(C) 2021 Author(s). This is an open access article licensed under the Creative Commons

Attribution-NonCommercial-NoDerivatives 4.0 International

(https://creativecommons.org/licenses/by-nc-nd/4.0/)

\section{GENDER DIFFERENCES IN ATTITUDES OF STUDENTS ATTENDING NON-INCLUSIVE SCHOOL TOWARDS INCLUSIVE PHYSICAL EDUCATION}

\author{
Dagmar Nemček ${ }^{1}$, Julie Wittmannová ${ }^{2}$ \\ ${ }^{1}$ Comenius University in Bratislava, Faculty of Physical Education and Sports, Slovakia \\ ${ }^{2}$ Palacky University Olomouc, Faculty of Physical Culture, Czech Republic
}

\begin{abstract}
Summary: The objective of the study was to determine and compare the attitudes of high school students of the non-inclusive school towards inclusive physical education according to gender. This study deepened the knowledge about the students' attitudes toward the inclusion of students with physical and intellectual disabilities. The research sample comprised a total of 181 able-bodied high school students (56 boys and 125 girls) attending one non-inclusive high school in Bratislava, Slovakia. Modified Czech version of the CAIPE (Children's Attitude toward Inclusive Physical Education) questionnaire was used as a primary research method. Girls presented higher levels of positive attitudes towards inclusive physical education (IPE) in goal achievement, motivation, and motor skills learning. Boys showed a higher level of positive attitudes in the self-confidence of students with disabilities through IPE. In the goal achievement, girls expressed a significantly higher positive attitude towards IPE in students with intellectual disabilities inclusion ( $U=2817, p=0.029, r=0.168$ ). The highest level of a positive attitude toward IPE declared both genders by society inclusion and the lowest level of positive attitude by motor skills acquisition. Slovak students of a non-inclusive high school showed a positive attitude toward IPE for the inclusion of pupils with physical as well as intellectual disabilities.
\end{abstract}

Keywords: inclusion, physical education, physical disability, intellectual disability, attitude, boys, girls.

\section{Introduction}

Inclusion and inclusive education have become increasingly common in pedagogy and special education, which can be described as international topics because the problem of 
inclusion is global. International studies (Kudláček et al. 2002; Meegean \& MacPhail 2006) tell us that with a growing number of students with disabilities being included in general physical education (P.E.), more and more P.E. teachers face the reality of teaching these students together with able-bodied students. In inclusive physical education (IPE), a student is attributed a share of the success of the whole class. The student sees that the success of the whole class also depends on him, thus stimulating the learner's motivation to learn and grow interested in the task at hand (Booth \& Ainscow 2011). IPE could help to change the attitudes and opinions of able-bodied students (Bailey 2005). In literature focused on the inclusion of students with disabilities toward P.E. classes and attitudes toward inclusion, it played a very important part in what is considered to be one of the key competencies of P.E. teachers (Hutzler 2012; Sherrill 2004). This is an important variable influencing the behaviour and interaction of able-bodied peers in IPE.

Attitudinal research in IPE has focused on the past thirty years in attitudes of P.E. teachers starting with research utilizing the theory of planned behaviour by Terry Rizzo (1984) followed by the inline of research using the theory of reasoned action (Downs \& Williams 1994; Rizzo \& Kirkendall 1995). Studies of students about IPE focus predominantly on experiences of students with special educational needs including students with different kinds of disabilities (Goodwin 2001; Bertills, Granlund \& Augustine 2019). Some studies focused on the impact of inclusion on students without disabilities (Obrusníková, Válková \& Block 2003; Ruijs \& Peetsma 2009; Kart \& Kart 2021). Slininger, Sherrill \& Jankowski (2000) declare, if attitudes towards the inclusion of pupils with disabilities are positive, the process of inclusion of the students is easier to achieve and result in it being more successful. Female students show a more positive attitude toward inclusion, and these attitudes are associated with empathy and social dominance (Navarro-Mateu et al. 2020; Průžek et al. 2020).

Inclusive education is a result of an inclusive philosophy in which the acceptance of children with disabilities and their inclusion among able-bodied children is the primary goal (Janoško 2011). However, it is also characterized by a change in the attitudes of both kinds of students and also school. Schools, so-called inclusive schools must be able to help students with disabilities overcome the barriers that arise and help them to adequately develop their skills (UNESCO 2017).

The study aims to determine the attitudes of Slovak students attending non-inclusive school towards inclusive physical education. Furthermore, this study should deepen the knowledge of the students' attitudes about the inclusion of students with physical and intellectual disabilities and compare it between boys and girls high school students. 


\section{Material and methods}

\section{Participants}

The research sample comprised a total of 181 able-bodied high school students attending one non-inclusive high school in Bratislava, Slovakia. 56 male high school students (boys; mean age of $17.3 \pm 1.2$ years) and 125 female high school students (girls; mean age of $17.1 \pm$ 1.1 years) participated in the questionnaire survey. Participants meeting the following criteria were included: (1) able-bodied (healthy) students; (2) attending non-inclusive high school; (3) without any experience with students with disabilities in P.E. classes. The exclusion criteria for all participants were students with special educational needs. Able-bodied high school students attending non-inclusive high schools were informed of the purpose of the research and the procedure for filling out the questionnaire. The questionnaire was completed in the presence of their headteacher and the researcher. In this study, informed consent was obtained from all participants. The research was approved by the Ethics Committee of the Faculty of Physical Education and Sports, Comenius University in Bratislava, Slovakia (No. 10/2019).

\section{Research design}

We were inspired by a standardized diagnostic tool an attitudinal questionnaire entitled CAIPE-R (Children's Attitude toward Inclusive Physical Education-Revised) developed and validated by American scholar Martin Block (Block 1995). The CAIPE-R is generalizable to more than one disability label and appears to be a valid and reliable instrument measuring attitudes of children without disabilities towards including children with disabilities in P.E. Modified Czech version (CAIPE-CZ) of the questionnaire (Kudláček, Ješina \& Wittmannová 2011) was translated in the Slovak language (Nemček \& Bumbera 2021). The questionnaire consists of basic questions, where we were informed about each student (gender, age, class, and place of residence). Further, the questionnaire informs us if the student had experience with children with disabilities in physical education. Other information was the description of the student with physical and intellectual disability. The last part of the questionnaire consisted of 5 following statements toward inclusion of students with physical and intellectual disabilities in P.E. classes: (1) The advantage of joint exercise students with disabilities in IPE is in achieving goals together (goals achievement), (2) Exercising with students with disabilities in IPE motivates able-bodied students to joint physical activities increasingly (motivation), (3) Students with disabilities will learn motor skills faster in IPE classes (motor skills acquisition), (4) Self-confidence of students with disabilities in IPE is strengthened (self-confidence) and (5) Integration of students with disabilities in IPE classes is important for their social inclusion 
(social inclusion). Each statement was accompanied by a 5-point scale from point 1 (strongly disagree) to point 5 (strongly agree). Overall students' attitudes were calculated by summarizing scores of all 5 statements. A higher mean point score meant a more positive attitude and a lower point score more negative attitude toward the inclusion of students with a physical and intellectual disability through P.E. classes. We considered a positive evaluation of inclusion when the statement reached a mean score of $5.00-3.50$ points, an indifferent attitude to inclusion when the statement reached a mean score of $3.49-2.49$ points, and a negative attitude to inclusion when the statement achieved $2.50-1.00$ points of the mean score.

\section{Statistical analysis}

The program IBM SPSS Statistics version 23.0 was used for data processing. The data were described using absolute and relative frequencies, including the mean $(\overline{\mathrm{x}})$ and standard deviation $( \pm \mathrm{SD})$. The Non-parametric Mann-Whitney U-test was used to assess differences in able-bodied students' attitudes between two independent samples according to gender (boys versus girls). Wilcoxon Signed Rank Test was used to assess the differences in attitudes toward inclusion between two related samples of students with physical disability and intellectual disability inside boys' and girls' groups. The significance level was set at $\alpha \leq 0.05\left(^{*}\right)$ and $\alpha \leq$ $0.01(* *)$. In the current study, only one measurement has been made and two main groups of able-bodied students according to the gender formed the study.

\section{Results}

Analysing the mean scores of expressed attitudes about goal achievement through IPE we found that girls compared to boys expressed a more sympathetic attitude with the statement that "The advantage of exercising students with disabilities in IPE is in achieving goals together" (Table 1,2). Girls more than boys agreed that if students with physical and intellectual disabilities will be integrated into P.E. classes all students (able-bodied and with disabilities) will achieve the same goals together. The application of the Mann Whitney U-test revealed a significantly higher positive attitude to inclusion in girls compared to boys. Girls of the present study were significantly more likely to agree that the advantage of exercising students with intellectual disabilities and able-bodied students in IPE is in achieving goals together $(\mathrm{U}=2817$, $\mathrm{p}=0.029, \mathrm{r}=0.168$ ) (Table 2). No significant differences in attitudes between boys and girls were found on the inclusion of a student with a physical disability neither in the total score of the statements. Both evaluated groups of boys ( $3.54 \pm 1.16$ points) and girls ( $3.82 \pm 1.03$ points) have taken a positive attitude towards inclusion as they agreed that the advantage of exercising 
students with physical/intellectual disabilities and able-bodied students in IPE is in achieving goals together (Figure 1).

In the field of motivation of able-bodied students through IPE, we found that girls more likely than boys agreed that "Exercising of students with disabilities in IPE motivates ablebodied students to joint physical activities increasingly". Even the higher mean scores, at the same time a more favourable opinion, were displayed by girls compared to boys, application of Mann Whitney U-test did not reveal significant differences in this statement between assessed groups of students (Table 1, 2). Both, boys (3.74 \pm 1.13 points) and girls (3.94 \pm 1.06 points) have taken a positive attitude towards inclusion as they agreed that exercising students with physical and intellectual disabilities in IPE motivates able-bodied students to join physical activities (Figure 1).

Table 1

Attitudes towards IPE of student with physical disability

\begin{tabular}{|l|c|c|c|c|}
\hline \multirow{2}{*}{ Statement } & \multicolumn{1}{|c|}{$\begin{array}{c}\text { Boys } \\
(\mathbf{n = 5 6})\end{array}$} & $\begin{array}{c}\text { Girls } \\
(\mathbf{n = 1 2 5})\end{array}$ & \multicolumn{2}{c|}{ Mann-Whitney U Test } \\
\cline { 2 - 5 } & \multicolumn{2}{|c|}{$(\mathbf{m e a n} \pm \mathbf{~ S D})$} & $\boldsymbol{U}$ & $\boldsymbol{p}$ \\
\hline goals achievement & $3.64 \pm 1.34$ & $3.81 \pm 1.15$ & 3327 & 0.581 \\
\hline motivation & $3.84 \pm 1.14$ & $3.99 \pm 1.07$ & 3223 & 0.370 \\
\hline motor skills acquisition & $3.63 \pm 1.36$ & $3.62 \pm 1.17$ & 3380 & 0.704 \\
\hline self-confidence & $3.82 \pm 1.06$ & $3.66 \pm 1.09$ & 3216 & 0.363 \\
\hline social inclusion & $4.07 \pm 1.02$ & $4,16 \pm 1.07$ & 3268 & 0.444 \\
\hline
\end{tabular}

Note: Higher mean score indicates more positive attitude towards IPE; U = Mann-Whitney U Test statistics; $p=$ statistical significance $(p$-values $* \leq .05, * * \leq .01)$

Table 2

Attitudes towards IPE of student with intellectual disability

\begin{tabular}{|l|c|c|c|c|}
\hline \multirow{2}{*}{ Statement } & \multicolumn{2}{|c|}{$\begin{array}{c}\text { Boys } \\
(\mathbf{n = 5 6})\end{array}$} & $\begin{array}{c}\text { Girls } \\
(\mathbf{n = 1 2 5})\end{array}$ & \multicolumn{2}{c|}{ Mann-Whitney U Test } \\
\cline { 2 - 5 } & \multicolumn{2}{|c|}{$(\mathbf{m e a n} \pm \mathbf{~ S D})$} & $\boldsymbol{U}$ & $\boldsymbol{p}$ \\
\hline goals achievement & $3.45 \pm 1.19$ & $3.83 \pm 1.06$ & $2817 *$ & 0.029 \\
\hline motivation & $3.64 \pm 1.23$ & $3.88 \pm 1.15$ & 3095 & 0.194 \\
\hline motor skills acquisition & $3.45 \pm 1.29$ & $3.58 \pm 1.18$ & 3325 & 0.580 \\
\hline self-confidence & $3.77 \pm 0.95$ & $3.54 \pm 1.07$ & 3085 & 0.185 \\
\hline social inclusion & $4.18 \pm 0.92$ & $4.04 \pm 1.07$ & 3308 & 0.530 \\
\hline
\end{tabular}

Note: Higher mean score indicates more positive attitude towards IPE; U = Mann-Whitney U Test statistics; $p=$ statistical significance $(p$-values $* \leq .05, * * \leq .01)$

Mean scores analyses of the third statement showed the equal score in both genders of expressed opinion that "Students with physical disabilities will learn motor skills faster in IPE classes" (Table 1). Even female high school students displayed a more positive attitude in motor skills acquisition of students with intellectual disability in IPE classes, calculation of Mann 
Whitney U-test did not reveal significant differences in opinions between boys and girls in the statement (Table 2). Both assessed groups of high school students, boys (3.54 \pm 1.21 points) and girls $(3.60 \pm 1.04$ points $)$ have taken in this statement a positive attitude towards the inclusion of students with physical and intellectual disabilities in IPE (Figure 1).

Analysing the mean scores of expressed students' opinions about self-confidence towards IPE we found that boys compared to girls expressed a more sympathetic attitude that "Self-confidence of students with physical and intellectual disabilities in IPE is strengthened" (Table 1,2). Calculation of Mann-Whitney U-test did not reveal significant differences between boys and girls high school students in this opinion. Both boys (3.79 \pm 0.95 points) and girls $(3.60 \pm 1.04$ points) have taken a positive attitude towards inclusion through the statement telling about the self-confidence of students with disabilities by IPE (Figure 1).

In the last statement, telling that "Integration of students with disabilities in IPE classes is important for their social inclusion" we see a highly positive attitude expressed by an ablebodied student toward IPE classes (Table 1, 2). Boys together with girls achieved a mean score value higher than 4.0 points in the opinion about the inclusion of students with physical and intellectual disabilities. No significant differences were revealed by Mann-Whitney U-test application between samples in opinions telling that integration of students with disabilities in IPE classes is important for their social inclusion (Figure 1).

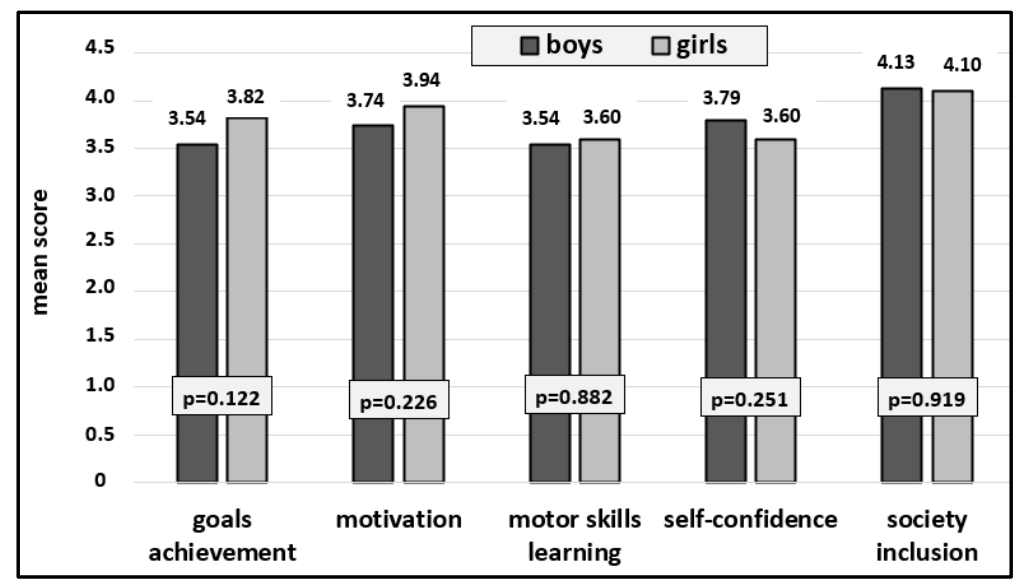

Figure 1

Attitudes' total scores towards IPE

Summarizing attitudes towards IPE, we found that girls presented higher levels of positive attitudes in the statements of goal achievement, motivation, and motor skills acquisition compared to boys. On the other hand, boys showed a higher level of positive attitudes in the statements of self-confidence compared to girls. The same level, as well as the most positive 
attitude toward IPE, declared both evaluated samples of high school students by the statement of society inclusion through IPE. No significant differences were found between boys' and girls' attitudes' total scores toward IPE in the case of the inclusion of students with physical and intellectual disabilities in P.E. classes (Figure 1).

Analysing the overall attitude of able-bodied students, we declare by both genders a positive attitude toward inclusion of students with physical as well as intellectual disabilities. Similar overall attitude of both genders was declared also by the total score. No significant differences were found between boys and girls in attitudes toward the inclusion of students with physical/intellectual disabilities in P.E (Figure 2).

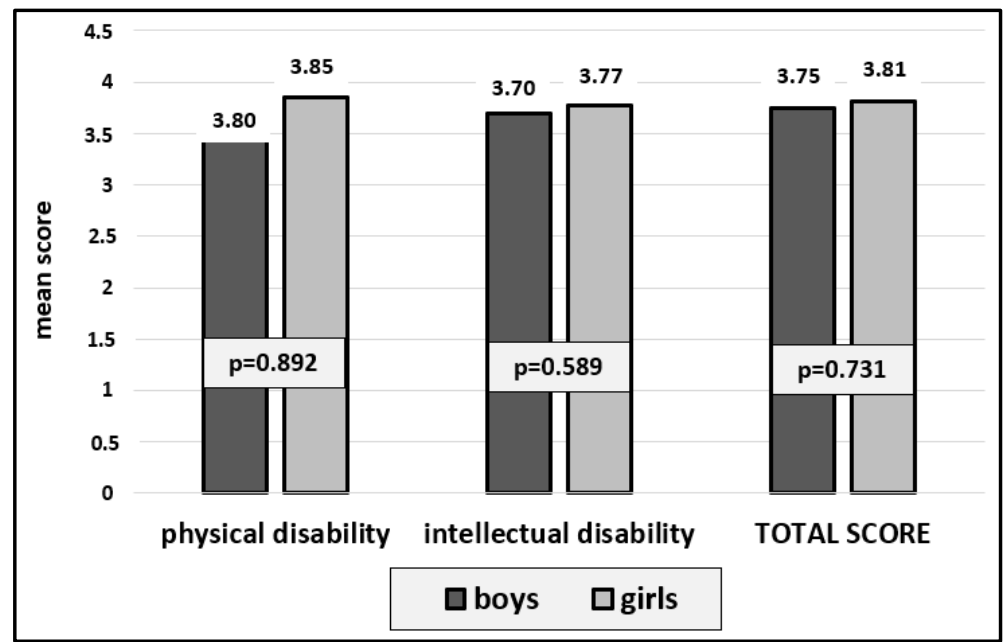

Figure 2

Overall attitude towards IPE

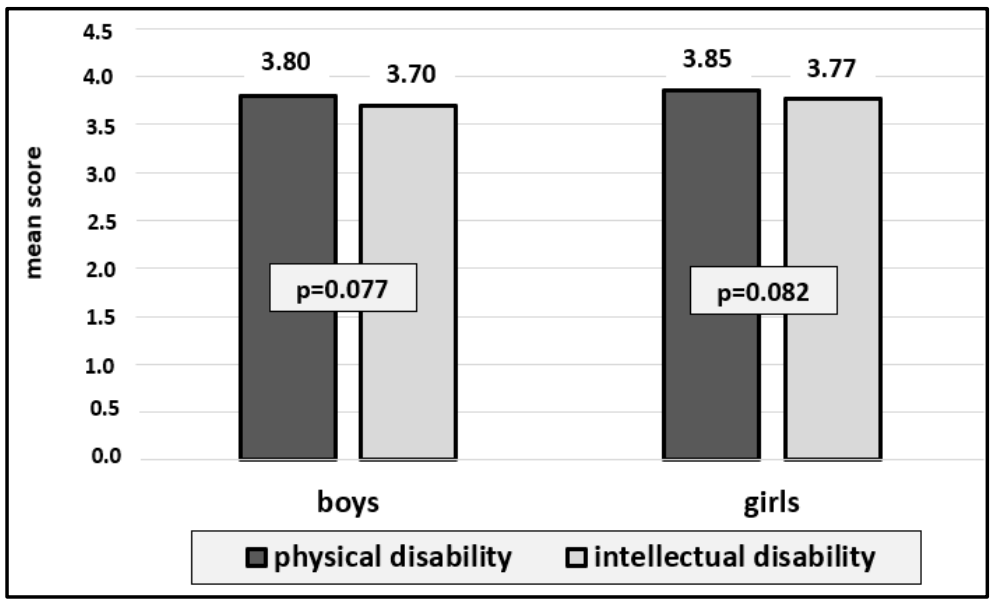

Figure 3

Differences between disabilities towards IPE

In the last comparison, we tried to find out which disability inclusion perceive boys and girls more positively or negatively in P.E. classes. By mean scores evaluation, both genders of 
high school students perceived the inclusion of a student with a physical disability in P.E. classes more positively than the inclusion of a student with an intellectual disability. However, the application of Wilcoxon's T-test did not reveal significant differences in the attitudes toward inclusion of students with physical nor intellectual disabilities in the P.E. classes in both groups of high school students according to gender (Figure 3). This establishes approximately the same opinion in both the boys' and girls' groups about the inclusion of both physically and mentally handicapped students in P.E. classes in high schools.

\section{Discussion}

The present study aimed to determine the attitudes of Slovak able-bodied high school students towards IPE, especially for the inclusion of students with physical and intellectual disabilities in P.E. classes. Able-bodied high school students presented their attitudes in five main statements towards IPE: goal achievement, motivation, motor skills acquisition, selfconfidence, and society inclusion. There were no significant differences found between boys and girls either in attitude towards IPE. Girls of the present study were significantly more likely to agree that the advantage of exercising students with intellectual disabilities and able-bodied students in IPE is in achieving goals together. Our research findings are consistent with the results of Wilhite, Biren \& Spencer (2012), who have found that joint exercise of people with intellectual disabilities and able-bodied individuals helps both groups to achieve common goals. People with intellectual and developmental disabilities in the above-mentioned study reported benefits of improved muscle tone, more strength, more energy, improved mood, less stress, healthier eating habits, more health awareness, better sleep patterns, more alertness, greater socialization opportunities, and renewed interest. Their able-bodied caregivers reported that joint exercises allowed them to do something positive to themselves while spending quality time with their adult child or sibling with an intellectual and developmental disability (Wilhite, Biren \& Spencer 2012).

In general, students with disabilities enjoy P.E. classes. Kurková (2018) found, that students with visual disabilities have a higher percentage of positive attitudes than students who are deaf or hard of hearing in indicators: popularity, importance, students' efforts, and their feelings towards P.E. classes (Kurková 2019). On one hand, the phenomenon of IPE from the perspective of students with disabilities shows good days in the themes of sense of belonging, skill full participation, and sharing in the benefits. On the other hand, the bad days the students with physical disabilities in IPE feel in the themes of social isolation questioned competence, 
and restricted participation (Goodwin 2000). Some other studies show also negative attitudes toward P.E. lessons in students with disabilities. Kurková \& Nemček (2016) found significant differences in attitudes expressed by students with disabilities if for some reason a regular P.E. lesson is canceled. The highest degree of happiness was observed in the students with physical disabilities, while the highest degree of pity was declared by students with visual disabilities. Authors also found that the biggest reason for inactivity of students with a physical disability during P.E. lessons is their laziness; for students who are deaf and hard of hearing inconvenient conditions; and for students with visual disability thoughts about their next subjects (Kurková \& Nemček 2018). The degree of popularity of P.E. is often related to the level of a pupil's successful gaining of movement skills, the level of intensity of specific exercises, and their degree of difficulty, all of which affect the pupil's ability to display their personality.

We have found that boys and girls have taken a positive attitude towards inclusion as they agreed that exercising students with physical and intellectual disabilities in IPE motivates able-bodied students to join physical activities. Authors Pan et al. (2011) in their study concluded that adolescents with autism spectrum disorders had lower motives toward IPE than adolescents without autism spectrum disorders, and external regulation was important in facilitating physical activity participation in adolescents with autism spectrum disorders. The study of Tristani et al. (2021) confirmed, that participation in inclusive physical activity has a motivating character for children with disabilities in social inclusion, secondary health conditions reduction, optimized physical functioning, and overall well-being improvement. Results of Vogler et al. (2021) study indicate that the IPE class where a child with severe spastic diplegic cerebral palsy was included was highly effective in time engagement and management. The qualitative nature of inclusion was one of widespread social acceptance and successful motor participation. The results of Seymour, Reid \& Bloom (2021) study showed four conceptual categories that motivate students with disabilities in IPE, that is the development of friendship, best friend, preferred physical activities and outcomes, and dealing with a disability. The results of the study further demonstrated the key characteristics of best friends and the influential role they play.

Motor skill acquisition is one of the primary goals of P.E. and IPE (Bendíková 2016; Bendíková \& Dobay 2017; Bendíková, Marko \& Šmída 2018). The results of the present study show a positive attitude of able-bodied students in motor skills learning of students with physical and intellectual disabilities in IPE classes. Results of other studies also confirm that an inclusive physical activity program is an effective method for improving the social skills and motor skills of students with autism spectrum disorder (Sansi, Nalbant \& Ozer 2021). The 
results of this study also demonstrated that an inclusive physical activity program is an effective method for developing the motor skills in typical development peers and creating positive changes in their attitudes. Strategies of universal design for learning, instructional support, incorporation of student choice, and use of multiple media in instruction (e.g., video, verbal, kinesthetics, and photography) significantly contribute to increased success in motor skills learning in IPE (Gilbert 2019). For students who are deaf and hard of hearing, teachers may need to make some basic modifications to their inclusion strategies, visual instruction, communication styles, peer tutoring, and socialization techniques to help these students reach their full potential, including quality motor skill acquisition (Schultz et al. 2013; Kurková \& Scheetz 2016). To facilitate the learning of motor skills in IPE, teachers are increasingly taking an ecological approach to assessment and instruction (Goodwin 2000b). In this approach, curriculum activities are categorized by function and intention (i.e., moving from one point to another, propelling a stationary object). Achieving the outcome of the task (e.g., getting the ball into the opponent's court) takes precedent overachieving the 'correct' movement form (Davis \& Burton 1991). Students, with the support of the teacher, try to identify the movement form that best meets the desired outcome. Movement solutions are often determined through exploration and self-discovery by the student and direct instruction by the teacher (Burton \& Davis 1996).

The results of the present study further revealed a positive attitude of able-bodied students towards inclusion through the statement telling about the self-confidence of students with disabilities by IPE. On one hand in the study of Todorovich (2013) P.E. teachers believed that in IPE is a possibility of negative results, such as a lowering of self-esteem and selfconfidence for students with disabilities and even a possible lack of confidence on the part of the P.E. teachers. On the other hand, the study of Hunt \& McDonnel (2007) confirms, that the benefits of inclusion are many and important, mainly by improving the community and developing the self-confidence and self-respect of the disability student by helping him integrate smoothly into the formal classroom and later into society. Also, in the current study, we see a very high positive attitude of able-bodied students by the expression that integration of students with disabilities in IPE classes is important for their social inclusion. P.E. is considered to have a high potential for fostering social inclusion (Block 2016). Talbot (2001) claims that P.E. helps children to develop respect for others and enhances social development. Individual student variables are significant for the social inclusion of students with disabilities (Furrer et al. 2020). School performance of students (Huber 2009), behavioural characteristics (Schwab et al. 2014; Garrote et al. 2017) and cognitive ability (Frederickson \& Furnham 1998) has a considerable impact on the social inclusion of students with disabilities in IPE classes. 
Gender (DeBoer et al. 2012), psychomotor clumsiness (Ruiz-Pérez et al. 2018), and class variables like class climate (Gasser et al. 2017) heterogeneity (Grütter, Meyer \& Glenz 2014) and class size (Park, Younghwan \& Block 2014) also play an important role in social acceptance and interactions. Using an appropriate teaching strategy in IPE allows full integration into the student environment. Students with disabilities feel more comfortable, changing attitude toward themselves, manifested in the appropriate perception, finding camouflage disabilities struggle with her self-presentation (DeLeeuw, DeBoer \& Minnaert 2019).

\section{Conclusion}

The findings of this study confirmed a positive attitude toward inclusive physical education for the inclusion of pupils with physical as well as intellectual disabilities in both genders of students of the non-inclusive high school. The highest level of a positive attitude toward IPE declared both genders of high school students by society inclusion through IPE and the lowest level of positive attitude by motor skills acquisition in IPE. Girls compared to boys presented significantly higher positive attitudes in achieving goals in IPE by exercising students with intellectual disabilities together with able-bodied students. It is necessary to continue this line of this research field with stress on exploring the attitudes of able-bodied students toward inclusive physical education by the inclusion of students with sensory disabilities, those who are deaf or hard of hearing, and visually impaired. In further research, we consider it important to focus on the opinions of P.E. teachers in Slovak non-inclusive schools, their readiness and willingness to teach pupils with different kinds of disabilities and with other special educational needs.

\section{Acknowledgments}

This scientific research was supported by the grant projects of the Ministry of Education, Science, Research and Sport of the Slovak Republic VEGA No. 1/0409/19 and KEGA No. 051UK-4/2022.

\section{References}

1. BAILEY, R., 2005. Evaluating the relationship between physical education, sport and social inclusion. In: Educational Review. 57(1), pp. 71-90. 
2. BENDÍKOVÁ, E., 2016. Curricular transformation of education on the field of physical and sport education in Slovakia. In: European Journal of Contemporary Education. 18(4), pp. 410-417.

3. BENDÍKOVÁ, E. \& B. DOBAY, 2017. Physical and Sport Education as a Tool for Development of a Positive Attitude toward Health and Physical Activity in Adulthood. In: European Journal of Contemporary Education. 6(1), pp. 14-21.

4. BENDÍKOVÁ, E., M. MARKO \& L. ŠMÍDA, 2018. Influence of Change in Content of Physical and Sport Education as Case Study on Level of Dynamic Function of Spine among Secondary School Female Students. In: European Journal of Contemporary Education. 7(4), pp. 633-641.

5. BERTILLS, K., M. GRANLUND \& L. AUGUSTINE, 2019. Inclusive teaching skills and student engagement in physical education. In: Frontiers in Education. 4(74), pp. 1-13.

6. BLOCK, M.E., 1995. Development and validation of children's attitudes toward integrated physical education-revised (CAIPE-R) inventory. In: Adapted Physical Activity Quarterly. 12(1), pp. 60-77.

7. BLOCK, M.E., 2016. A Teacher's Guide to Adapted Physical Education: Including Students with Disabilities in Sports and Recreation. London: Brookes Publishing.

8. BООТН, T. \& M. AINSCOW, 2011. Index for Inclusion: developing learning and participation in schools. Bristol: Centre for Studies on Inclusive Education.

9. BURTON, A.W. \& DAVIS, W.E., 1996. Ecological task analysis utilizing intrinsic measures in research and practice. In: Human Movement Science. 15(2), pp. 285-314.

10. DAVIS, W.E. \& A.W. BURTON, 1991. Ecological Task Analysis: Translating Movement Behavior Theory into Practice. In: Adapted Physical Activity Quarterly. 8(2), pp. 154-177.

11. DeBOER, A., S.J. PIJL, W. POST \& A. MINNAERT, 2012. Peer Acceptance and Friendships of Students with Disabilities in General Education: The Role of Child, Peer, and Classroom Variables. In: Social Development. 35(3), pp. 831-844.

12. DeLEEUW, R.R., A. DeBOER \& A. MINNAERT, 2019. What do Dutch general education teachers do to facilitate the social participation of students with SEBD?" In: International Journal of Inclusive Education. 35(4), pp. 1-24.

13. DOWNS, P. \& T. WILLIAMS, 1994. Student attitudes toward integration of people with disabilities in activity settings: A European comparison. In: Adapted Physical Activity Quarterly. 11(1), pp. 32-43.

14. FREDERICKSON, N.L. \& A.F. FURNHAM, 1998. Sociometric-status-group classification of mainstreamed children who have moderate learning difficulties: An 
investigation of personal and environmental factors. In: Journal of Educational Psychology. 90(4), pp. 772-783.

15. FURRER, V., S. VALKANOVER, M. ECKHART \& S. NAGEL, 2020. The role of teaching strategies in social acceptance and interactions; Considering students with intellectual disabilities in inclusive physical education. In: Frontiers in Education. 5, pp. 586960.

16. GARROTE, A., R. SERMIER DESSEMONTET \& E. MOSER OPITZ, 2017. Facilitating the social participation of pupils with special educational needs in mainstream schools: A review of school-based interventions. In: Educational Research and Reviews. 20(4), pp. 1223.

17. GASSER, L., J. GRÜTTER, L. TORCHETTI \& A. BUHOLZER, 2017. Competitive classroom norms and exclusion of children with academic and behavior difficulties. In: Journal of Applied Developmental Psychology. 49, pp. 1-11.

18. GILBERT, E.N., 2019. Designing Inclusive Physical Education with Universal Design for Learning. In: Journal of Physical Education, Recreation and Dance. 90(7), pp. 15-21.

19. GOODWIN, D.L., 2000. Inclusive physical education: ecological instruction approaches and the use of adaptation and modification. In: Journal CAHPERD. 66(1), pp. 12-13.

20. GOODWIN, D.L., 2001. Meaning of help in PE: Perceptions of students with physical disabilities. In: Adapted Physical Activity Quarterly. 18(3), pp. 189-303.

21. GOODWIN, D. \& E. WATKINSON, 2000. Inclusive physical education from the perspective of students with physical disabilities. In: Adapted Physical Activity Quarterly. 17(2), pp. 144-160.

22. GRÜTTER, J., B. MEYER \& A. GLENZ, 2014. Sozialer Ausschluss in Integrationsklassen: Ansichtssache? In: Psychologie in Erziehung und Unterricht. 62(1), pp. 65-82.

23. HUBER, C., 2009. Soziale Ausgrenzung in der Integration von Schülern mit sonderpädagogischem Förderbedarf: Zusammenhang von Persönlichkeit, Gruppenheterogenität und sozialer Ausgrenzung. In: Empirische Pädagogik. 23, pp. 170190.

24. HUNT, P. \& J. McDONNELL, 2007. Inclusive Education. In: Odom SL, Horner RH, Snell ME, Blacher J, editors. Handbook of Developmental Disabilities. New York: The Guilford Press; 2007. pp. 269-291.

25. HUTZLER, Y., 2012. Attitudes toward the participation of individuals with disabilities in physical activity: A review. In: Quest. 55(4), pp. 347-373. 
26. JANOŠKO, P., 2011. Inclusive education - Its benefits, perspectives and limits in the context of the Slovak Republic. In: e-Pedagogium. 11(3), pp. 97-104.

27. KART, A. \& M. KART, 2021. Academic and social effects of inclusion on students without disabilities: A review of the literature. In: Education Sciences. 11(16), pp. 1-13.

28. KUDLÁČEK, M., O. JEŠINA \& J. WITTMANNOVÁ, 2011. Structure of a questionnaire on children's attitudes towards inclusive physical education (CAIPE-CZ). In: Acta Universitatis Palackianae Olomucensis. Gymnica. 41(4), pp. 43-48.

29. KUDLÁČEK, M., H. VÁLKOVÁ, C. SHERRILL, B. MYERS \& R. FRENCH, 2002. An inclusion instrument based on planned behavior theory for prospective Czech physical educators. In: Adapted Physical Activity Quarterly. 19(3), pp. 280-299.

30. KURKOVÁ, P. \& D. NEMČEK, 2016. Attitudes of students with disabilities towards physical education lessons: Reasons for their indifference and preference for leisure time activities. In: Journal of Physical Education and Sport. 16(1), pp. 222-229.

31. KURKOVÁ, P. \& D. NEMČEK, 2018. Preferences and reasons for the lack of interest of Czech teenagers with sensory disability in physical education classes. In: Physical Activity Review. 6, pp. 171-180.

32. KURKOVÁ, P. \& N.A. SCHEETZ, 2016. Communication Strategies Used by Physical Education Teachers and Coaches in Residential Schools for the Deaf in the U.S. In: Acta Facultatis Educationis Physicae Universitatis Comanianae. 56(1), pp. 1-15.

33. KURKOVÁ, P., 2018. Attitudes of Czech pupils who are deaf or hard of hearing toward physical education classes: A comparison of gender differences. In: Acta Gymnica. 48(2), pp. 83-90.

34. KURKOVÁ, P., 2019. Comparison of differences students' viewing in the Czech elementary schools for the deaf in physical education classes with other studies. In: Physical Activity Review. 7, pp. 168-174.

35. MEEGEAN, S. \& A. MacPHAIL, 2006. Irish physical educators' attitude toward teaching students with special educational needs. In: European Physical Education Review. 12(1), pp. 75-97.

36. NAVARRO-MATEU, D., J. FRANCO-OCHOA, S. VALERO-MORENO \& V. PRADOGASCÓ, 2020. Attitudes, Sentiments, and Concerns About Inclusive Education of Teachers and Teaching Students in Spain. In: Frontiers in Psychology. 11(521), pp. 1-11.

37. NEMČEK, D. \& P. BUMBERA, 2021. Názory žiakov druhého stupňa základných škôl na integrované vyučovanie telesnej a športovej výchovy [Opinions of second grade primary 
school pupils on integrated physical education]. In: Telesná výchova \& šport. 31(2), pp. 3439.

38. OBRUSNÍKOVÁ, I., H. VÁLKOVÁ \& M.E. BLOCK, 2003. Impact of inclusion in general physical education on students without disabilities. In: Adapted Physical Activity Quarterly. 20(3), pp. 230-245.

39. PAN, C.Y., C.L. TSAI, CH. CHU \& K.W. HSIEH, 2011. Physical activity and selfdetermined motivation of adolescents with and without autism spectrum disorders in inclusive physical education. In: Research in Autism Spectrum Disorders. 5(2), pp. 733741.

40. PARK, S.S., K.O.H. YOUNGHWAN \& M.E. BLOCK, 2014. Contributing Factors for Successful Inclusive Physical Education. In: Palaestra. 28(1), pp. 42-49.

41. PRŮŽEK, M., I. CIHOVÁ, D. NOVAK, X. WANG, J. VAŠÍČKOVÁ, L. TOMÁNEK \& B. ANTALA, 2020. Inclusion in physical education on the basis of opinions of high school female students from Slovakia, Czech Republic and Croatia. In: Journal of Physical Education and Sport. 20(3), pp. 1538-1542.

42. RIZZO, T.L. \& D.R. KIRKENDALL, 1995. Teaching Students with Mild Disabilities: What Affects Attitudes of Future Physical Educators? In: Adapted Physical Activity Quarterly. 12(3), pp. 205-216.

43. RIZZO, T.L., 1984. Attitudes of physical educators toward teaching handicapped pupils. In: Adapted Physical Activity Quarterly. 1(4), pp. 267-274.

44. RUIJS, N.M. \& T. PEETSMA, 2009. Effect of inclusion on students with and without special educational needs. In: Educational Research Review. 4(2), pp. 67-79.

45. RUIZ-PÉREZ, L.M., M. PALOMO-NIETO, M.A. GÓMEZ-RUANO \& J.A. NAVIAMANZANO, 2018. When We Were Clumsy: Some Memories of Adults who were Low Skilled in Physical Education at School. In: Journal of Physical Education Sports Management. 5(1), pp. 30-36.

46. SANSI, A., S. NALBANT \& D. OZER, 2021. Effects of an Inclusive Physical Activity Program on the Motor Skills, Social Skills and Attitudes of Students with and without Autism Spectrum Disorder. In: Journal of Autism and Developmental Disorders. 51, pp. 2254-2270.

47. SCHULTZ, J.L., L.J. LIEBERMAN, M.K. ELLIS \& L.C. HILGENBRINCK, 20113. Ensuring the Success of Deaf Students in Inclusive Physical Education. In: Journal of Physical Education, Recreation and Dance, 2013; 84(5): 51-56. 
48. SCHWAB, S., M. GEBHARDT, M. KRAMMER \& B. GASTEIGER-KLICPERA, 2014. Linking self-rated social inclusion to social behaviour. An empirical study of students with and without special education needs in secondary schools. In: European Journal of Special Needs Education. 30(1), pp. 1-14.

49. SEYMOUR, H., G. REID \& G.A. BLOOM, 2021. Friendship in inclusive physical education. In: Adapted Physical Activity Quarterly. 26(3), pp. 201-219.

50. SHERRILL, C., 2004. Adapted physical activity, recreation and sport: Cross-disciplinary and lifespan. 6th ed. Boston: Mc Graw-Hill.

51. SLININGER, D., C. SHERRILL \& C.M. JANKOWSKI, 2000. Children's Attitudes Toward Peers with Severe Disabilities: Revisiting Contact Theory. In: Adapted Physical Activity Quarterly. 17(2), pp. 176-196.

52. TALBOT, M., 2001. The case for physical education. In: Doll-Tepper G, Scoretz D, editors. World Summit on Physical Education. Germany, Berlin: ICSSPE, pp. 39-50.

53. TODOROVICH, J., 2013. Chinese teachers' beliefs about inclusive physical education. In: Journal of Physical Education, Recreation and Dance. 84(2), 13.

54. TRISTANI, L., J. TOMASONE, H. GAINFORTH \& R. BASSETT-GUNTER, 2021. Taking steps to inclusion: A content analysis of a resource aimed to support teachers in delivering inclusive physical education. In: International Journal of Disability, Development and Education. 68(1), pp. 116-135.

55. UNESCO, 2017. A guide for ensuring inclusion and equity in education. Paris: UNESCO Publishing.

56. VOGLER, E.W., P. KORANDA \& T. ROMANCE, 2021. Including a child of severe cerebral palsy in physical education: A case study. In: Adapted Physical Activity Quarterly. 17(2), pp. 161-175.

57. WILHITE, B., G. BIREN \& L. SPENCER, 2012. Fitness Intervention for Adults with Developmental Disabilities and their Caregivers. In: Therapeutic Recreation Journal. 46(4), pp. 245-267. 